\title{
DESCRIPTION OF A NEW SPECIES OF THE GENUS ARGANIELLA GIUSTI \& PEZZOLI, 1980 (MOLLUSCA, GASTROPODA, HYDROBIIDAE) FROM THE IBERIAN PENINSULA
}

\author{
B. Arconada* \& M. ${ }^{a}$ A. Ramos**
}

\begin{abstract}
A new species of Arganiella Giusti \& Pezzoli, 1980, up to now a monotypic genus, thought to be endemic to the Italian Central Apennines, is described from the Iberian Peninsula. This new species, named Arganiella tartessica, is located in southwestern Spain, provinces of Huelva and Badajoz. In this paper, a detailed description of its morphological characters is given and new data of nervous system and ciliated areas in the cephalic region are provided.
\end{abstract}

Key words: Mollusca, Hydrobiidae, Arganiella, taxonomy, Spain, Iberian Peninsula.

\section{RESUMEN}

Descripción de una nueva especie del género Arganiella Giusti y Pezzoli, 1980 (Mollusca, Gastropoda, Hydrobiidae) en la Península Ibérica

Se describe una especie ibérica de Arganiella Giusti y Pezzoli, 1980, un género que hasta ahora se consideraba monotípico y endémico de los Apeninos centrales italianos. Esta nueva especie, denominada Arganiella tartessica, ha sido localizada en el sureste español, en las provincias de Huelva y Badajoz. En este artículo se describen en detalle sus caracteres morfológicos y se presentan datos, hasta la fecha desconocidos en el género Arganiella, del sistema nervioso y de áreas ciliadas en la región cefálica.

Palabras clave: Mollusca, Hydrobiidae, Arganiella, taxonomía, España, Península Ibérica.

\section{Introduction}

Until now, Arganiella was considered a monotypic genus known from the Italian Central Apennines with $A$. pescei Giusti \& Pezzoli, 1980 as its type species. This genus is closely related only to genus Heraultiella (Bodon et al., 2002), which is also represented by a single species Heraultiella exilis (Bodon et al., 2001 as Heraultia exilis; renamed as Heraultiella exilis in Bodon et al., 2002), located in the south of France (Hérault). Heraultiella exilis, first described as Valvata exilis Paladilhe, 1867, was considered the representative species of the genus Horatia in Western Europe (Boeters, 1974). Later,

* Museo Nacional de Ciencias Naturales (CSIC), Departamento de Biodiversidad y Biología Evolutiva. José Gutiérrez Abascal, 2. 28006 Madrid. España. (*)mcna313@mncn.csic.es (**)m.ramos@mncn.csic.es 
Bouchet (1990) cited it as Arganiella exilis. Differences between Heraultiella exilis and the type species of genera Horatia (H. klecakiana Bourguignat 1887) and Arganiella (A. pescei), are mainly found in the female and male genitalia (Bodon et al., 2001; Giusti \& Pezzoli, 1980). Heraultiella is characterized by only one distal seminal receptacle and a very large bursa copulatrix with a very long slender duct; the penis is rather long, having a short, wide gradually tapering basal portion, and an apical portion ending in a very pointed tip. The bursa is similar in Horatia spp. but with two seminal receptacles, the distal larger than the proximal, which is thin and bent to adhere to the renal oviduct at the level of the loop; the penis is rather elongated and slender with single or double lobes, evident on the left side at $2 / 3$ of its length. Finally, Arganiella has a large bursa, sack-like or kidney shaped, with a rather short duct and one distal seminal receptacle; the penis is flat, slightly dilated subapically with a short apical portion.

In Spain, Heraultiella exilis has been reported from Granada (Alonso, 1975; Vidal-Abarca \& Suárez, 1985: as Valvata exilis) and Barcelona (Bech, 1990: as Horatia exilis), although only based on shell material. Therefore, these identifications need to be revised.

A new species, discovered some years ago (see Arconada, 2000 and type material in this paper), was found in the southwestern region of the Iberian Peninsula. After comparing a great number of morphological characters it clearly showed closer relationships with the type species of Arganiella (A. pescei) than with species of any other genera. It was hence included in the genus Arganiella. New characters from the nervous system and body ciliation are now reported. This new species clearly differs from Heraultiella exilis, basically in genitalia and radular features.

The presence of one species of the genus Arganiella in Spain (only cited previously from Italy) supports the close biogeographical relationship between molluscan freshwater faunas from separated areas of the western Mediterranean, and, at the same time, reinforces the Mediterranean basin as the area with the highest diversity of species of the family Hydrobiidae in Europe (Arconada \& Ramos, 2003).

\section{Material and Methods}

Field collections, anatomical studies and morphometric measurements are described in Ramos et al. (2000). The number of specimens studied for morphometry, localities and sampling dates are indicated in the corresponding section in the text. The morphological descriptions are based on terminology from Hershler \& Ponder (1998). Scanning Electron Microscope (SEM) photographs were made with a Philips XL20 following the methodology described in Ramos et al. (2000). All specimens where collected alive and are currently preserved in $70 \%$ ethanol.

Localities are listed according to the code: fountain, stream or spring, municipality, province, UTM co-ordinates, sampling date, museum catalogue number and collector's initials (see abbreviations below). Locality names and UTM co-ordinates were obtained from the official Army Geographical Service map (1:50.000 series).

Several shells of Heraultiella exilis lent by A. Bertrand, from sediments of Boyne-Addisan, Hérault (France), were also examined.

Statistical analyses: All statistics (mean value, standard deviation and coefficient of variation) were calculated using STATVIEW for Macintosh, and standardized in order to avoid the effect of the measurement scale.

ABBREVIATIONS USED IN THE TEXT, TABLES AND FIGURES Shell and operculum characters: AH: aperture height. AL: aperture length. AW: aperture width. LBW: length of body whorl. NL: length of opercular nucleus. NW: width of opercular nucleus. NSW: number of spire whorls. OL: operculum length. OW: operculum width. OLWL: length of the last whorl of the operculum. OLWW: width of the last whorl of the operculum. SL: shell length. SW: shell width. WAW: width of the antepenultimate whorl. WBW: width of the body whorl. WPW: width of the penultimate whorl. CV: coefficient of variation. SD: standard deviation.

Anatomical characters. Ag: albumen gland. Bc: bursa copulatrix. $\mathrm{Cg}$ : capsule gland. DBC: duct of the bursa copulatrix. Os: osphradium. P: penis. Pl: penial lobe. Po: pallial oviduct. Pp: pseudopenis. Pr: prostate. Ro: renal oviduct. SR1: distal seminal receptacle. SR2: proximal seminal receptacle. Ss: style sac. St: stomach. Vc: ventral channel of capsule gland. L: length. W: width. The concentration of the nervous system was determined by the "RPG" ratio (Davis et al., 1976): length of right pleural-supraoesophageal commissure/lengths of right pleural ganglion, supraoesophageal ganglion, and commissure.

Collections. MNCN: Museo Nacional de Ciencias Naturales, Madrid, Spain. 


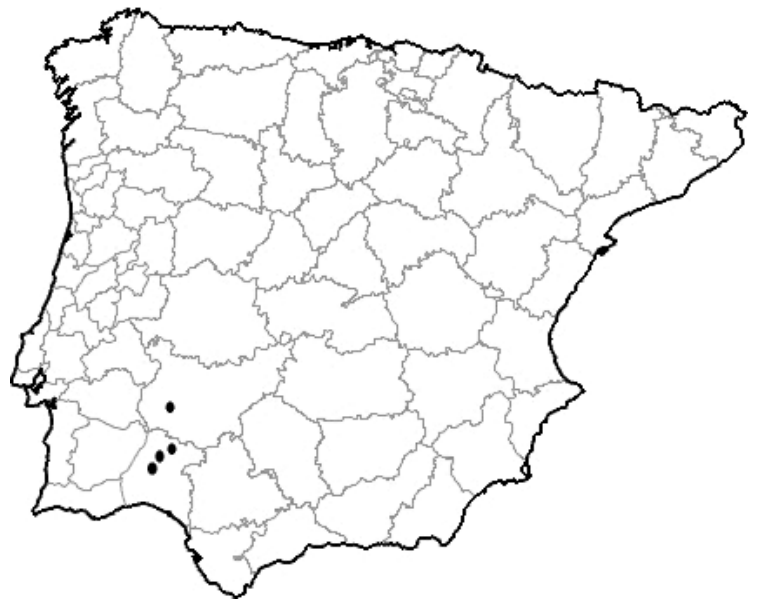

Fig. 1.- Map showing localities where Arganiella tartessica is found in Huelva and Badajoz provinces (Iberian Peninsula).

Fig. 1.- Mapa mostrando las localidades donde se ha encontrado Arganiella tartessica en las provincias de Huelva y Badajoz (Península Ibérica).

Collectors: R. A.: R. Araujo, B. A.: B. Arconada, E. R.: E. Rolán, S. J.: S. Jiménez, L.B.: D. Bragado.

\section{Results}

\section{Arganiella tartessica sp. nov.}

TYPE MATERIAL: Holotype (Fig. 2A) and four paratypes (Figs. 2B, F, I, K) are gold coated shells. These specimens plus other 53 paratypes in $70 \%$ ethanol are deposited in MNCN (catalog $\mathrm{n}^{\mathrm{o}} 15.05 / 47037$ ) as well as one SEM stub with 12 opercula and another with three radula. The material was collected in a Fountain in Cortelazor, Huelva; UTM: 29SQB0801; 16/7/1989 MNCN (15.05/47037), col. E.R. One specimen was collected later 25/6/1997 (MNCN no 15.05/47038); col. R.A. y L.B.

TYPE LOCALITY: Fountain en Cortelazor, Huelva. UTM: 29SQB0801.

ADDITIONAL MATERIAL STUDIED: Specimens of this species were also collected in the following localities: Fountain in Irrigation canal in Fuenteheridos, Huelva; UTM: 29SQB0597; 15/7/1989 (MNCN 15.05/47039), 25/6/1997 (MNCN 15.05/47040); col: E.R., R.A. and L.B. Hermitage Virgen de los Ángeles, Peña de Arias Montano, Alajar, Huelva; UTM: 29SQB052949; 15/7/1989 (MNCN 15.05/47041), 25/6/1997 (MNCN 15.05/47042); col: E.R.. R.A. and L.B. Abariego spring, Valle de Santa Ana, Badajoz; UTM: 29SPC931488; 22/11/1996 (MNCN 15.05/47043); col: B.A. and S.J. La Regina spring, Valle de Santa Ana, Badajoz; UTM: 29SPC931488; 14/10/1992 (MNCN 15.05/47044); col: E.R.

\section{DESCRIPTION}

Shell. Depressed-trochiform or valvatiform (Table 1), 3.5 whorls (Figs. 2A-J); shell length 1.33$0.98 \mathrm{~mm}$, shell width $1.71-1.20 \mathrm{~mm}$; protoconch pitted consisting of 1.5 whorls (Figs. 2O-P); protoconch width and width of the nucleus are 348 $\mu \mathrm{m}$ and $126 \mu \mathrm{m}$, respectively; peristome complete, thin; aperture prosocline, almost completely roundish, rarely inclined towards the umbilicus (Fig. 2D); umbilicus wide (Figs. 2K-M), $354 \mu \mathrm{m}$ in diameter, frequently carrying a single egg capsule inside, rarely 2 or 3 small ones (Figs. 2L, N); periostracum yellowish-translucent.

Operculum. Corneous, paucispiral, thin, oval-rounded (Figs. 3A-B; Table 2); the pale yellowish nucleus is located in a central position.

Body. This species has two kinds of cephalic

Table 1.- Shell measurements (in mm) of Arganiella tartessica: 1- Cortelazor, Huelva (type locality); 2- Fuenteheridos, Huelva; 3- Valle de Santa Ana, Badajoz

Tabla 1.- Medidas de la concha (en mm) de Arganiella tartessica: 1- Cortelazor, Huelva (localidad tipo); 2- Fuenteheridos, Huelva; 3- Valle de Santa Ana, Badajoz.

\begin{tabular}{lccc}
\hline & $\mathbf{1}$ & $\mathbf{2}$ & $\mathbf{3}$ \\
\cline { 2 - 4 } & $\begin{array}{c}\text { Mean } \pm \text { SD; CV } \\
(\text { Max-Min }) \\
(\mathrm{n}=30)\end{array}$ & $\begin{array}{c}\text { Mean } \pm \text { SD; CV } \\
(\text { Max-Min }) \\
(\mathrm{n}=12)\end{array}$ & $\begin{array}{c}\text { Mean } \pm \text { SD; CV } \\
(\text { Max-Min }) \\
(\mathrm{n}=20)\end{array}$ \\
\hline SL & $1.15 \pm 0.08 ; 0.07$ & $1.18 \pm 0.08 ; 0.07$ & $1.36 \pm 0.12 ; 0.07$ \\
& $(1.33-0.98)$ & $(1.33-1.03)$ & $(1.65-1.20)$ \\
SW & $1.49 \pm 0.08 ; 0.06$ & $1.33 \pm 0.07 ; 0.05$ & $1.58 \pm 0.12 ; 0.08$ \\
& $(1.71-1.37)$ & $(1.50-1.20)$ & $(1.73-1.29)$ \\
SL/SW & $0.77 \pm 0.05 ; 0.07$ & $0.88 \pm 0.04 ; 0.04$ & $0.86 \pm 0.08 ; 0.09$ \\
& $(0.91-0.63)$ & $(1.0-0.85)$ & $(1.07-0.72)$ \\
AH & $0.77 \pm 0.04 ; 0.05$ & $0.76 \pm 0.04 ; 0.05$ & $0.87 \pm 0.04 ; 0.05$ \\
& $(0.87-0.70)$ & $(0.84-0.69)$ & $(0.97-0.76)$ \\
LBW & $1.02 \pm 0.08 ; 0.07$ & $1.05 \pm 0.08 ; 0.12$ & $1.19 \pm 0.11 ; 0.09$ \\
& $(1.18-0.84)$ & $(0.95-0.61)$ & $(1.47-1.06)$ \\
WBW & $1.11 \pm 0.08 ; 0.07$ & $1.02 \pm 0.05 ; 0.05$ & $1.23 \pm 0.15 ; 0.12$ \\
& $(1.29-0.98)$ & $(1.11-0.89)$ & $(1.75-1.03)$ \\
AL & $0.70 \pm 0.03 ; 0.05$ & $0.72 \pm 0.05 ; 0.06$ & $0.82 \pm 0.07 ; 0.09$ \\
& $(0.79-0.61)$ & $(0.79-0.64)$ & $(0.95-0.65)$ \\
AW & $0.61 \pm 0.03 ; 0.05$ & $0.59 \pm 0.03 ; 0.06$ & $0.71 \pm 0.05 ; 0.06$ \\
& $(0.69-0.58)$ & $(0.65-0.53)$ & $(0.78-0.61)$ \\
WPW & $0.53 \pm 0.05 ; 0.10$ & $0.49 \pm 0.05 ; 0.11$ & $0.60 \pm 0.04 ; 0.07$ \\
& $(0.66-0.44)$ & $(0.58-0.42)$ & $(0.70-0.54)$ \\
WAW & $0.23 \pm 0.03 ; 0.11$ & $0.26 \pm 0.06 ; 0.23$ & $0.25 \pm 0.02 ; 0.10$ \\
& $(0.28-0.18)$ & $(0.40-0.20)$ & $(0.30-0.20)$ \\
NSW & $3.5 \pm 0.0 ; 0.0$ & $3.39 \pm 0.13 ; 0.03$ & $3.75 \pm 0.25 ; 0.06$ \\
& $(\mathrm{n}=8)$ & $(3.5-3.25)$ & $(4.00-3.25)$ \\
\hline & & &
\end{tabular}




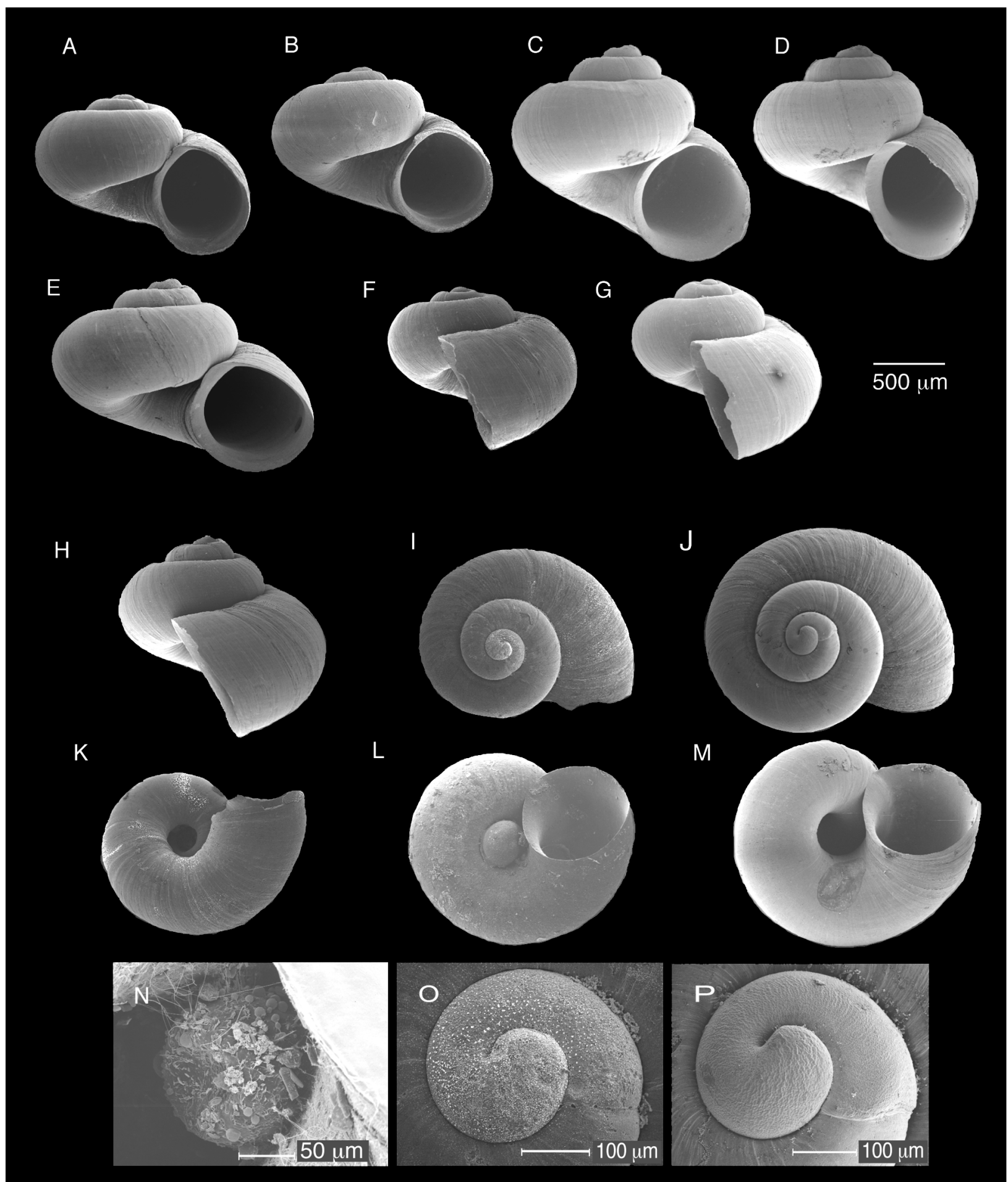

Fig. 2.- Shells of Arganiella tartessica. A, B, F, I, K and O. Cortelazor, Huelva (type locality); C, D, G, L and M. Valle de Santa Ana, Badajoz. A. Holotype (MNCN 15.05/47037); O, P. Protoconch. L and N. Egg capsule inside the umbilicus. Scale bar Figs. A-M: $500 \mu \mathrm{m}$; N: $50 \mu \mathrm{m}$; O-P: $100 \mu \mathrm{m}$. Abbreviations in text.

Fig. 2.- Conchas de Arganiella tartessica. A, B, F, I, K y O. Cortelazor, Huelva (localidad tipo); C, D, G, L y M. Valle de Santa Ana, Badajoz. A. Holotipo (MNCN 15.05/47037); O, P. Protoconcha. L y N. Cápsula con huevo dentro del ombligo. Escala en las Figs. A-M: $500 \mu \mathrm{m}$; N: $50 \mu \mathrm{m}$; O-P: $100 \mu \mathrm{m}$. Abreviaturas en el texto. 


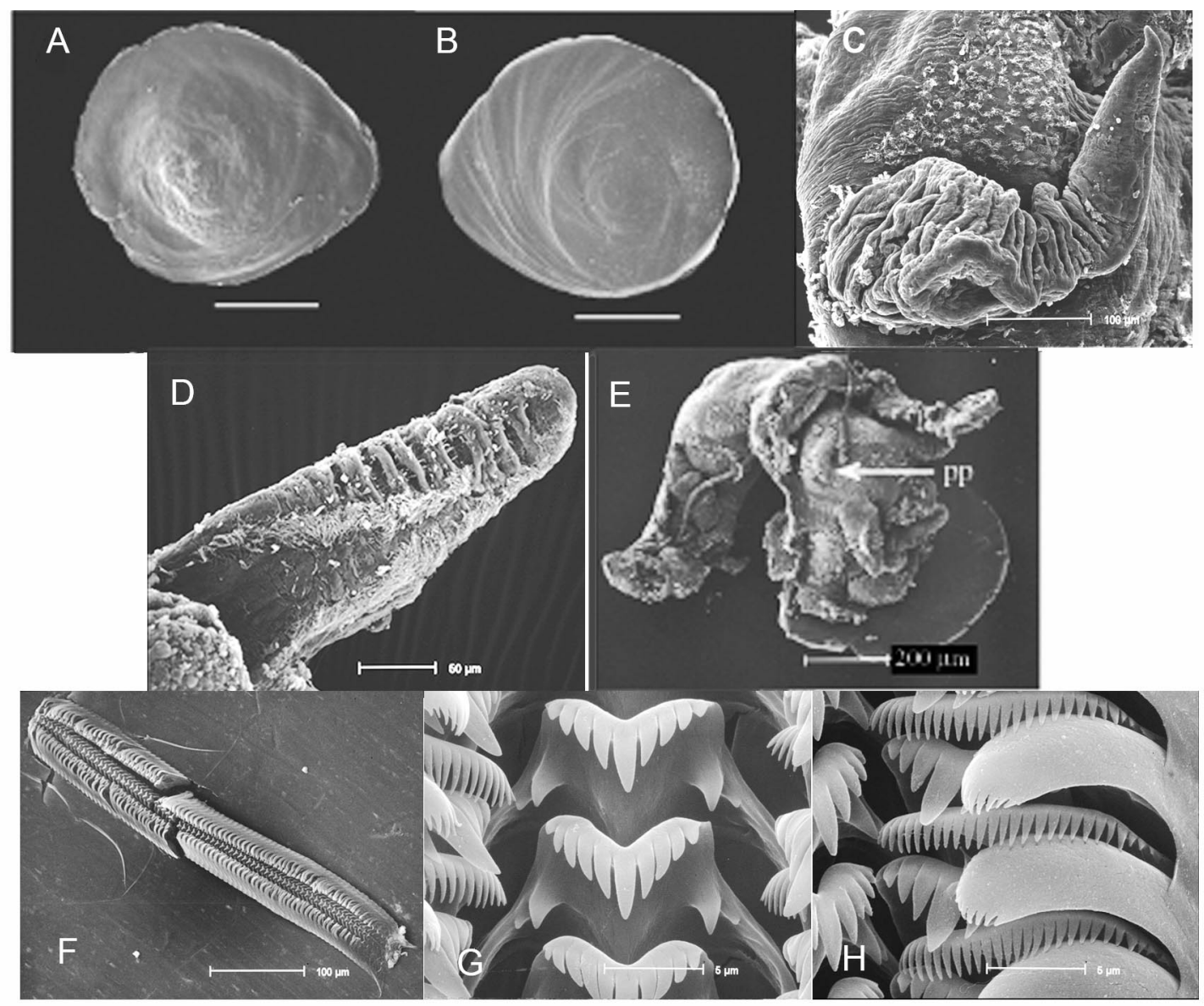

Fig. 3.- Operculum, body and radula of Arganiella tartessica. A, B, F, G and H. Cortelazor, Huelva (type locality); C-E: Fuenteheridos, Huelva; A-B: Internal and external side of the operculum; C: Head of a male and penis. Detail of the ciliated area; D: Ciliated band of the cephalic tentacles; E: Female pseudopenis; F-H: Radula. Scale bar Figs. A, B and E: $200 \mu \mathrm{m}$; C and F: $100 \mu \mathrm{m}$; D: $50 \mu \mathrm{m}$; G-H: $5 \mu \mathrm{m}$. Abbreviations in text.

Fig. 3.- Fig. 3. Opérculo, cuerpo y rádula de Arganiella tartessica. A, B, F, G y H. Cortelazor, Huelva (localidad tipo); C-E: Fuenteheridos, Huelva; A-B: Lado interno y externo del opérculo; C: Cabeza y pene de un macho. Detalle del área ciliada; D: Banda de cilios en los tentáculos cefálicos; E: Pseudopene de una hembra; F-H: Rádula. Escala en las Figs. A, B y E: $200 \mu \mathrm{m}$; C y F: $100 \mu \mathrm{m}$; D: $50 \mu \mathrm{m}$; G-H: $5 \mu \mathrm{m}$. Abreviaturas en el texto.

pigmentation. Some specimens (Fig. 4A) have a dark head, with pigment fading towards the snout and tentacles having a central dark band, while other specimens are slightly pigmented with some dark areas around the eye spots and in the upper margin of the snout (Fig. 4B). The pigmentation of the tentacles also has a central dark band. Both types of cephalic pigmentation are found in specimens from the same population; eye spots present.

One specimen observed at the SEM showed a ciliated area in the right part of the head, between the eye and the base of the penis (Fig. 3C). Cephalic tentacles have a ciliated band all along their right lateral part (Fig. 3D).

External body pigmentation is completely dark, except for the last whorl, where it is possible to distinguish the rectum loop by transparency.

Nervous system. The right and left ganglia are about the same size (Figs. 4C-D). The left pleural ganglion is slightly bigger than the right one. There is a long supraesophageal connective and a very short subesophageal connective. The oesophagus makes a loop posterior to the cerebral commissure. Nervous system measurements are: 
Table 2.- Operculum measurements (in mm) of Arganiella tartessica from Cortelazor, Huelva (type locality).

Tabla 2.- Medidas del opérculo (en mm) de Arganiella tartessica de Cortelazor, Huelva (localidad tipo).

\begin{tabular}{ccccccc}
\hline $\mathbf{O L}$ & $\mathbf{O W}$ & $\mathbf{O L W L}$ & $\mathbf{O L W W}$ & $\mathbf{N L}$ & $\mathbf{N W}$ & $\mathbf{O L} / \mathbf{O W}$ \\
\hline $0.60 \pm 0.04 ; 0.07$ & $0.52 \pm 0.03 ; 0.07$ & $0.22 \pm 0.01 ; 0.07$ & $0.17 \pm 0.01 ; 0.08$ & $0.24 \pm 0.01 ; 0.07$ & $0.32 \pm 0.03 ; 0.10$ & $1.16 \pm 0.05 ; 0.04$ \\
$(0.66-0.51)$ & $(0.55-0.42)$ & $(0.24-0.20)$ & $(0.18-0.14)$ & $(0.27-0,23)$ & $(0.36-0.26)$ & $(1.23-1.07)$ \\
$(\mathrm{n}=12)$ & $(\mathrm{n}=12)$ & $(\mathrm{n}=6)$ & $(\mathrm{n}=6)$ & $(\mathrm{n}=6)$ & $(\mathrm{n}=6)$ & $(\mathrm{n}=12)$ \\
\hline
\end{tabular}

length of the cerebral ganglia: $0.29 \mathrm{~mm}$; length of the right pleural ganglion: $0.19 \mathrm{~mm}$; length of the left pleural ganglion: $0.22 \mathrm{~mm}$; length of the subesophageal ganglion: $0.19 \mathrm{~mm}$; length of the supraesophageal ganglion: $0.16 \mathrm{~mm}$; length of the supraesophageal connective: $0.38 \mathrm{~mm}$; length of the subesophageal connective: $0.08 \mathrm{~mm}$. The RPG ratio is 0.51 .

Ctenidium-osphradium. Ctenidium with 14 lamellae, approximately (Fig. 4E); it occupies 3/4 of the length of the pallial cavity; osphradium oval, 2.5 times longer than wider (Table 3 ).

Digestive system. Style sac protruding anteriorly to intestinal loop (Fig. 4F, Table 3). Rectum forms a

Table 3.- Osphradium and digestive system measurements (in $\mathrm{mm}$ ) of Arganiella tartessica: 1- Cortelazor, Huelva (type locality); 2- Valle de Santa Ana, Badajoz.

Tabla 3.- Medidas del osfradio y del sistema digestivo (en $\mathrm{mm}$ ) de Arganiella tartessica: 1- Cortelazor, Huelva (localidad tipo); 2- Valle de Santa Ana, Badajoz.

\begin{tabular}{lcc}
\hline & $\mathbf{1}$ & $\mathbf{2}$ \\
\cline { 2 - 3 } & $\begin{array}{c}\text { Mean } \pm \text { SD;CV } \\
(\text { Max-Min }) \\
(\mathrm{n}=3)\end{array}$ & $\begin{array}{c}\text { Mean } \pm \text { SD;CV } \\
(\text { Max-Min }) \\
(\mathrm{n}=2)\end{array}$ \\
\hline Os L & $0.26 \pm 0.02 ; 0.0$ & $0.25 \pm 0.02 ; 0.097$ \\
& $(0.28-0.25)$ & $(0.27-0.24)$ \\
Os W & $0.09 \pm 0.01 ; 0.12$ & $0.10 \pm 0.00 ; 0.00$ \\
& $(0.10-0.08)$ & $(0.10)$ \\
Ss L & $0.38 \pm 0.05 ; 0.14$ & $0.37 \pm 0.05 ; 0.12$ \\
& $(0.44-0.34)$ & $(0.40-0.34)$ \\
Ss W & $0.23 \pm 0.04 ; 0.17$ & $0.30 \pm 0.06 ; 0.20$ \\
& $(0.27-0.19)$ & $(0.34-0.26)$ \\
St L & $0.54 \pm 0.16 ; 0.30$ & $0.46 \pm 0.06 ; 0.13$ \\
& $(0.72-0.41)$ & $(0.50-0.41)$ \\
St W & $0.43 \pm 0.06 ; 0.14$ & $0.50 \pm 0.09 ; 0.08$ \\
& $(0.47-0.36)$ & $(0.56-0.44)$ \\
\hline
\end{tabular}

gentle U-shape in the pallial cavity (Fig.4E). Radula typically taenioglossate; it is long $(0.48 \%)$ relative to mean shell dimension (Hershler \& Ponder, 1998) and has approximately 77 rows of teeth (Fig. 3F, Table 4); central tooth with two basal cusps at each side (Fig. 3G), the most external sometimes so small that it is difficult to distinguish; distance between internal cusps is $8.9 \mu \mathrm{m}$; this tooth has a long middle cusp and 5 long and pointed cusps at each side; cutting edge of the central tooth slightly concave and $\mathrm{V}$ shaped basal tongue; lateral tooth with 3-4 denticles on each side of a central one (Fig. 3H).

Male genitalia. The prostate is typically beanshaped and half of it extends inside the pallial cavity (Fig. 4G; Table 5); the anterior vas deferens can be seen near its middle part. Penis small and simple (Fig. 4H); it ends in a pointed, pigmented tip; this pigmentation is sometimes very difficult to distinguish; penial duct runs straight and lies towards the right edge of the penis.

Female genitalia. The renal oviduct makes a complete loop over the pallial gland (Fig. 4I; Table 5); bursa copulatrix pyriform and large relative to

Table 4.- Radula formulae and measurements (in $\mathrm{mm}$ ) of Arganiella tartessica from Cortelazor, Huelva (type locality).

Tabla 4.- Fórmula y medidas de la rádula (en $\mathrm{mm}$ ) de Arganiella tartessica de Cortelazor, Huelva (localidad tipo).

\begin{tabular}{lc}
\hline Central teeth & $5+\mathrm{C}+5 / 2-2$ \\
Central teeth width & $\sim 8 \mu \mathrm{m}$ \\
Lateral teeth & $4-\mathrm{C}-3$ \\
Inner marginal teeth & $\geq 27$ cusps \\
Outer marginal teeth & $\geq 10$ cusps \\
Radula length & $\sim 560 \mu \mathrm{m}$ \\
Radula width & $\sim 79 \mu \mathrm{m}$ \\
Number of rows & $\sim 77$ \\
\hline
\end{tabular}


A

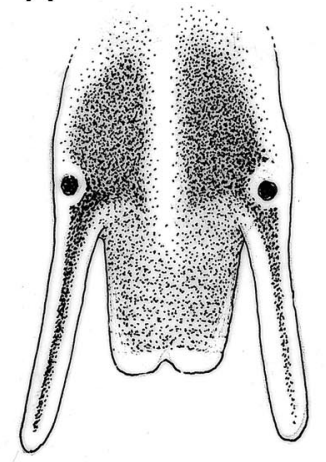

B

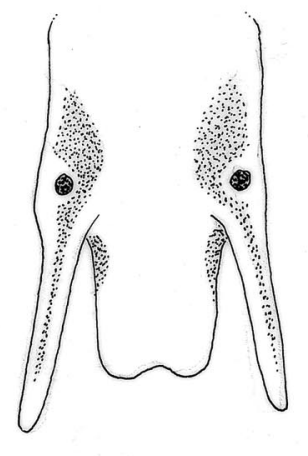

C

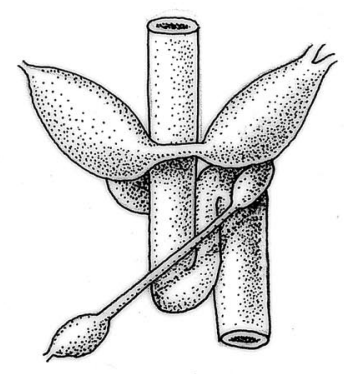

D

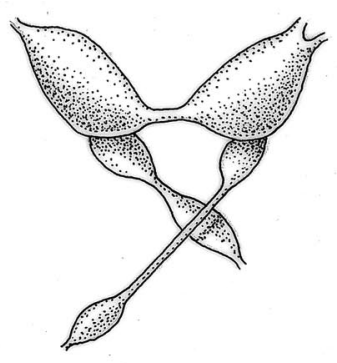

E

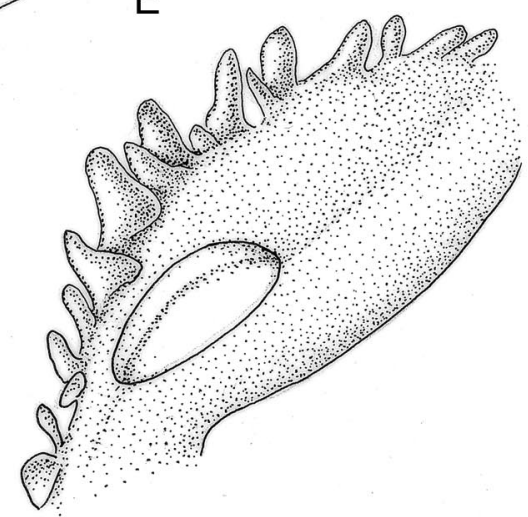

$\mathrm{F}$
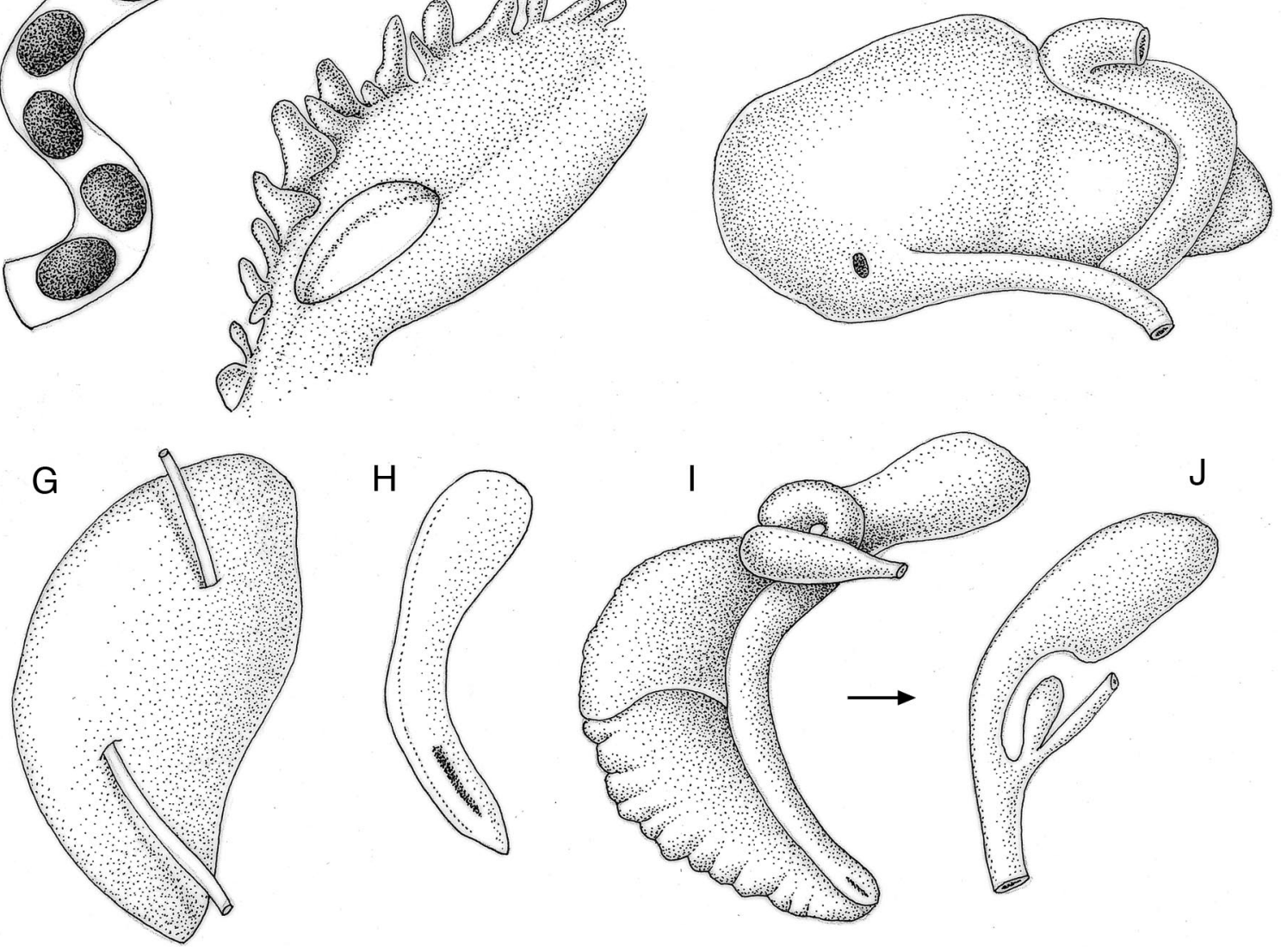

$\mathrm{H}$

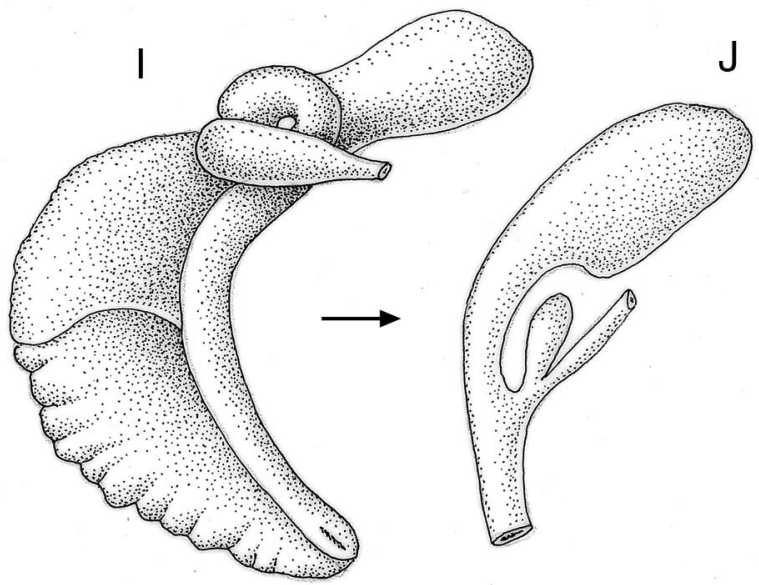

Fig. 4.- Anatomy of Arganiella tartessica. A-B: Different types of cephalic pigmentation; C-D: Partial nervous system; E: Rectum shape, ctenidium and osphradium; F: Stomach; G: Prostate; H: Penis; I-J: Anterior female genitalia. Scale bar $500 \mu \mathrm{m}$.

Fig. 4.- Anatomía de Arganiella tartessica. A-B: Diferentes tipos de pigmentación cefálica; C-D: Parte del sistema nervioso; E: Forma del recto, ctenidio y osfradio; F: Estómago; G: Próstata; H: Pene; I-J: Genitalia anterior femenina. Escala: $500 \mu \mathrm{m}$. 
Table 5.- Male and female genitalia measurements (in mm) of Arganiella tartessica: 1- Cortelazor, Huelva (type locality); 2Valle de Santa Ana, Badajoz; 3- Fuenteheridos, Huelva; 4- Alajar, Huelva.

Tabla 5.- Medidas del sistema genital masculino y femenino (en mm) de Arganiella tartessica: 1- Cortelazor, Huelva (localidad tipo); 2- Valle de Santa Ana, Badajoz; 3- Fuenteheridos, Huelva; 4- Alajar, Huelva.

\begin{tabular}{|c|c|c|c|c|}
\hline & 1 & 2 & 3 & 4 \\
\hline & $\begin{array}{c}\text { Mean } \pm \text { SD; CV } \\
\text { (Max-Min) }\end{array}$ & $\begin{array}{l}\text { Mean } \pm \text { SD; CV } \\
\text { (Max-Min) }\end{array}$ & $\begin{array}{l}\text { Mean } \pm \text { SD; CV } \\
\text { (Max-Min) }\end{array}$ & $\begin{array}{c}\text { Mean } \pm \text { SD; CV } \\
\text { (Max-Min) }\end{array}$ \\
\hline $\operatorname{Pr} \mathrm{L}$ & $\begin{array}{c}0.53 \pm 0.02 ; 0.04 \\
(0.55-0.52) \\
(\mathrm{n}=2)\end{array}$ & 0.59 & 0.74 & 0.59 \\
\hline Pr W & $\begin{array}{c}0.27 \pm 0.07 ; 0.25 \\
(0.31-0.22) \\
(\mathrm{n}=2)\end{array}$ & 0.25 & 0.4 & 0.33 \\
\hline P L & $\begin{array}{c}0.47 \pm 0.14 ; 0.30 \\
(0.56-0.37) \\
(\mathrm{n}=2)\end{array}$ & $\begin{array}{c}0.36 \pm 0.02 ; 0.07 \\
(0.38-0.34) \\
(\mathrm{n}=2)\end{array}$ & 0.64 & 0.56 \\
\hline $\mathrm{P} W$ & $\begin{array}{c}0.10 \pm 0.01 ; 0.12 \\
(0.11-0.09) \\
(\mathrm{n}=2)\end{array}$ & $\begin{array}{c}0.08 \pm 0.01 ; 0.07 \\
(0.09-0.08) \\
(n=2)\end{array}$ & 0.07 & 0.08 \\
\hline Po L & 0,72 & $\begin{array}{c}0.67 \pm 0.09 ; 0.13 \\
(0.73-0.60) \\
(n=2)\end{array}$ & 0.64 & 0.83 \\
\hline Po W & 0.36 & $\begin{array}{c}0.38 \pm 0.07 ; 0.18 \\
(0.42-0.33) \\
(n=2)\end{array}$ & 0.36 & 0.34 \\
\hline Ag. L & 0.23 & & 0.34 & 0.42 \\
\hline Cg. L & 0.48 & & 0.30 & 0.41 \\
\hline SR1 L & 0.14 & $\begin{array}{c}0.15 \pm 0.03 ; 0.24 \\
(0.17-0.12) \\
(n=2)\end{array}$ & 0.12 & \\
\hline $\mathrm{BC} \mathrm{L}$ & 0.34 & $\begin{array}{c}0.32 \pm 0.03 ; 0.09 \\
(0.34-0.31) \\
(\mathrm{n}=2)\end{array}$ & 0.27 & \\
\hline $\mathrm{BC} W$ & 0.16 & $\begin{array}{c}0.19 \pm 0.03 ; 0.14 \\
(0.21-0.17) \\
(n=2)\end{array}$ & 0.20 & \\
\hline $\mathrm{dBC} L$ & 0.17 & $\begin{array}{c}0.16 \pm 0.04 ; 0.26 \\
(0.19-0.13) \\
(\mathrm{n}=2)\end{array}$ & 0.19 & \\
\hline
\end{tabular}

the pallial oviduct (more than $1 / 3$ of the Po); the bursal duct is medium-sized; almost all of the bursa copulatrix protrudes posteriorly to the pallial gland; distal seminal receptacle elongated-pyriform, arising very near the point of origin of the duct of the bursa copulatrix (Fig.4J); almost $2 / 3$ of the pallial gland is located inside the pallial cavity.

A female from the Fuenteheridos population showed a small pseudopenis in similar position to that of the male penis (Fig. 3E); the rest of the geni- talia of this female was completely normal.

The egg capsules frequently found attached to the umbilicus measure around $245 \mu \mathrm{m}$ in diameter. They have one embryo each (observed in several samples at different stages of maturation), and are seen both in males and females.

ETYMOLOGY. The name tartessica is derived from Tartessos (a Hispanic Pre-Roman culture which inhabits a region called Tartéside, located in 
what is now West Andalusia).

HABITAT AND DISTRIBUTION. This species is known from the provinces of Huelva and Badajoz (Fig. 1). It is found in non-polluted springs, fountains and canals, on aquatic vegetation, stones, and wet walls.

\section{Discussion}

The species belonging to Horatia have two seminal receptacles, while the studied specimens have one distal seminal receptacle. Therefore, they can only be included either in Arganiella or in Heraultiella. The genus Arganiella is characterized by a very small shell, valvatiform to planispiral; an operculum without peg; penis without lobes; female genitalia with distal seminal receptacle and large, sac-like or kidney-shaped bursa copulatrix with anterior duct; central tooth with two pairs of basal cusps (Bodon et al, 2001; Giusti \& Pezzoli, 1980, 1981). The combination of characters here described clearly suggests it belongs in the genus Arganiella.

Arganiella tartessica can be distinguished from type species $A$. pescei by its taller shell, a greater number of spire whorls, body and head pigmentation (including eye spots), fewer lamellae, a longer style sac, a pyriform bursa copulatrix and a penis pigmented in its distal part. Arganiella tartessica shares several features with Heraultiella exilis, but is distinguished because the last has a very large bursa copulatrix, with a very long duct entering the bursa on the lateroposterior side, penis rather long, having a short, wide, gradually tapering basal portion, apical portion ending in a very pointed tip and a radula with one basal cusp on each side of the central tooth.

The cilia from the ciliated area observed in the right part of the head (Fig. 3C) of the studied specimens are short and grouped, and coincide with that described for Hauffenia wienerwaldensis Haase, 1992. This author (Haase, 1992) suggested that their function could be to improve locomotion in interstitial habitat.

Interpopulation variability is very low, and is based on the relative size of several characters of the shells and genitalia. Shells from the Valle de Santa Ana population are larger than the rest, with larger specimens showing 4 spire whorls. Aperture size of the shell is also larger. In relation to genital features, it is not possible to determine differences conclusively due to the scarce number of speci- mens available for comparison. Nevertheless, some differences are reported related to the size of the pallial gland, prostate and penis.

Arganiella tartessica is therefore the second species of the genus described to date. The great distance that separates the two species allows the prediction that other populations should exist. The description of the new species should not only help in reconstructing the evolutionary history of Mediterranean Hydrobiidae, but also should be considered in the initiatives whose objectives are conservation and management of these species and their habitat (Verdú \& Galante, 2006).

\section{ACKNOWLEDGEMENTS}

Our thanks to A. Bertrand for the loan of some shells of Heraultiella exilis and to Drs. D. Moreno and E. Rolán that made useful comments on the manuscript. J. Bedoya $(\dagger)$ at the MNCN made SEM photomicrographs. Drawings were re-done by I. Díaz Cortaberría. Sarah Young revised the English text. This work was funded by the "Fauna Ibérica" Project (DGES PB95-0235).

\section{References}

Alonso, M. R., 1975. Moluscos terrestres y dulceacuícolas de la depresión de Granada (España) y sus alrededores. Cuadernos de Ciencias Biológicas Universidad de Granada, 4: 125-157.

ArconadA, B., 2000. Contribución al conocimiento sistemático y filogenético de la familia Hydrobiidae (Mollusca, Prosobranchia) de la Península Ibérica. Doctoral dissertation. Universidad Autónoma de Madrid. 447 pp.

ArConAdA, B. \& Ramos, M. A., 2003. The Ibero-Balearic Region: one of the areas of highest Hydrobiidae (Gastropoda, Prosobranchia, Rissooidea) diversity in Europe. Graellsia, 59(2-3): 91-104.

BECH, M., 1990. Fauna malacológica de Catalunya. Molluscos terrestres i d'agua dolça. Treballs de la Institució Catalana d'Història Natural, 12: 1-229.

Bodon, M., Manganelli, G. \& Giusti, F., 2001. A survey of the European valvatiform Hydrobiid genera, with special reference to Hauffenia Pollonera, 1898 (Gastropoda: Hydrobiidae). Malacologia, 43(1-2): 1103-215.

Bodon M., Manganelli, G. \& Giusti, F., 2002. Heraultiella new name for Heraultia Bodon, Manganelli \& Giusti, 2001 (Gastropoda: Hydrobiidae). Journal of Conchology, 37(6): 681.

Boeters, H. D., 1974. Horatia Bourguignat, Plagigeyeria Tomlin und Litthabitella Boeters (Prosobranchia). Archiv für Molluskenkunde, 104: 85-92. 
BouCHET, P., 1990. La malacofauna française: endemisme, patrimonie natural et protection. Revue d'Écologie la Terre et la Vie, 45: 259-288.

Davis, G. M., Kitikoon, V. \& Temcharoen, P., 1976, Monograph on "Lithoglyphosis" aperta, the snail host of Mekong river schistosomiasis. Malacologia, 15(2): 241-287.

Giusti, F \& Pezzoli, E., 1980. Gasteropodi 2 (Gastropoda: Prosobranchia: Hydrobioidea, Pyrguloidea). Guide per il Ricoscimento delle Specie Animali delle Acque Interne Italiane, 8: 1-67.

Giusti, F. \& Pezzoli, E., 1981. Notulae malacologicae XXV. Hydrobioidea nuove o poco conosciute dell'Italia appenninica. Archiv für Molluskenkunde, 111: 207-222.

HAASE, M., 1992. A new stygobiont, valvatiform hydrobiid gastropod from Austria (Caenogastropoda: Hydrobiidae). Journal of Molluscan Studies: 58: 207-214.

Hershler, R. \& PONDER, W., 1998. A review of morphological characters of Hydrobioid snails. Smithsonian Contributions to Zoology, 600: 1-55.

Ramos, M. A., Arconada, B., Moreno, D. \& Rolán, E., 2000, A new genus and a new species of Hydrobiid snail (Mollusca:Gastropoda:Hydrobiidae) from eastern Spain. Malacologia, 42(1-2): 75-101.
Verdú, J. R. \& Galante, E. (Eds.), 2006. Libro Rojo de los Invertebrados de España. Dirección General para la Biodiversidad, Ministerio de Medio Ambiente, Madrid. 411 pp.

VidAl-ABARCA, C. \& SuÁREZ, M. L., 1985. Lista faunistica y biogeográfica de los moluscos (Gastropoda \& Bivalvia) de las agues dulces continentales de la Península Ibérica e Islas baleares. Asociación Española de Limnología (Publicación, $\mathrm{n}^{\circ}$ 2) y Edicions Universitat de Barcelona. Barcelona. 193 pp.
Recibido, 15-III-2007

Aceptado, 12-IV-2007 Publicado, 27-VI-2007 